\title{
Effect of T4 Modification of Host Valyl-tRNA Synthetase on Enzyme Action in vivo ${ }^{1}$
}

\author{
M. MARGARET COMER ${ }^{2}$ AND FREDERICK C. NEIDHARDT ${ }^{3}$ \\ Department of Biological Sciences, Purdue University, Lafavette, Indiana 47907, and Department of \\ Microbiology, The University of Michigan Medical School, Ann Arbor, Michigan 48104
}

Accepted May 14, 1975

\begin{abstract}
It has previously been found that bacteriophage $T 4$ modifies the valyl-tRNA synthetase of its host; in this work we have examined the effects of this modification on the action of the enzyme in vivo. For this purpose we compared the properties of $\mathrm{T} 4$-infected cells with those of uninfected cells or cells infected with the amber mutant $v s 2$, which by all available criteria seems to leave the host enzyme completely unmodified.

We find that, although the overall rate of transfer of valine into protein is reduced after infection, modification is apparently not the cause of this reduction. Also, modification does not alter the level of aminoacylation of the total valine tRNA pool nor of the invidividual species of valine tRNA. Nor does modification appear to be necessary to maintain these levels after infection. We found no evidence that modification affects any unknown valyl-tRNA synthetase reaction that yields novel valine-containing products. Although the modified enzyme is more stable in vitro than the unmodified enzyme, modification does not seem to facilitate phage growth at temperatures above the optimum.

To all appearances, therefore, T4-directed modification of the host valyl-tRNA synthetase does not detectably affect the in vivo catalytic action of the enzyme in any straightforward way, at least under prevailing laboratory conditions.
\end{abstract}

\section{INTRODUCTION}

Bacteriophage T4 modifies the valyltRNA synthetase of its bacterial host by the addition of a 10,000-molecular-weight, phage-coded subunit (Marchin et al., 1972). The properties of this modified enzyme have been extensively characterized in vitro. Compared with the unmodified enzyme, it has an increased molecular weight, an increased stability to heat and urea (Marchin et al., 1972), and a more tenacious binding of tRNA (Marchin et al.,

${ }^{1}$ This work is taken from a Ph.D. thesis submitted by M.M.C. to Purdue University.

${ }^{2}$ Present address: Fachbereich Biologie, Universität Regensburg, 84 Regensburg, Federal Republic of Germany.

${ }^{3}$ Present address: Department of Microbiology, The University of Michigan Medical School, Ann Arbor, Michigan 48104. Reprint requests should be directed to this author at this address.

Copyright (C) 1975 by Academic Press, Inc

All rights of reproduction in any form reserved.
1974). It has an altered requirement for monovalent cations (unpublished experiments), and unlike the normal enzyme it is able to charge yeast tRN $\Lambda$ (Marchin et al., 1972). Most of its enzymological properties, however, are unchanged in vitro. The apparent $K_{m}$ values for valine, ATP, and tRNA are very nearly the same for the two forms of the enzyme, as is the $\mathrm{pH}$ dependence. No natural amino acids other than valine are substrates for the modified enzyme. It charges the same tRNA species as the normal enzyme and at the same rate (Marchin et al., 1972).

In this paper we extend the analysis of the modified enzyme to include its functioning in vivo. The availability of a mutant phage that is unable to modify the host enzyme (McClain et al., 1975) made it possible to test a number of hypotheses otherwise inaccessible. 


\section{MATERIALS AND METHODS}

Bacterial and bacteriophage strains. NP4 is our strain of Escherichia coli B. B/5 was obtained from W. H. McClain. The bacteriophages used were $\mathrm{T} 4 \mathrm{~B}$ and $\mathrm{T} 4 \mathrm{Bc}{ }^{+}$, a variant of $\mathrm{T} 4 \mathrm{~B}$ that does not require tryptophan as a cofactor for adsorption; both are referred to as "wild-type T4" throughout this paper. Strain vs2 is a mutant of T4B that does not modify the host valyl-tRNA synthetase (McClain et al., 1975).

Media and method of cultivation. The minimal medium used was M9 medium containing $5.8 \mathrm{~g}$ of $\mathrm{Na}_{2} \mathrm{HPO}_{4}, 3.0 \mathrm{~g}$ of $\mathrm{KH}_{2} \mathrm{PO}_{4}, 0.5 \mathrm{~g}$ of $\mathrm{NaCl}$, and $1.0 \mathrm{~g}$ of $\mathrm{NH}_{4} \mathrm{Cl}$ per liter of water, supplemented with 1.0 $\mathrm{mM} \mathrm{MgSO}_{4}, 0.01 \mathrm{mM} \mathrm{FeCl}_{3}$, and $4.0 \mathrm{~g}$ of glucose per liter (all autoclaved separately).

Cultures were grown aerobically in Erlenmeyer flasks on a rotary shaker at the desired temperature. Growth was monitored by measuring the absorbance of the culture at $420 \mathrm{~nm}$ on a Zeiss PMQ II spectrophotometer. The efficacy of phage infection was routinely determined by measuring the number of surviving bacteria a few minutes after the addition of phage.

Fraction of valine $R N A$ present as valyl$t R N A$. Cells from a $500-\mathrm{ml}$ culture in late exponential phase were precipitated with $50 \mathrm{ml}$ of cold $50 \%$ trichloroacetic acid. After $20 \mathrm{~min}$ in an ice bath they were collected by centrifugation, washed with $0.25 M$ sodium acetate ( $\mathrm{pH} 5.5$ ), then resuspended in $10 \mathrm{ml}$ of the same buffer. An equal volume of phenol was added and the mixture was stirred at room temperature for 20 min. After centrifugation to separate the phases, the aqueous phase was removed; the phenol phase was reextracted with $5 \mathrm{ml}$ of buffer. RNA was then precipiatated from the combined aqueous phases with two volumes of cold ethanol for $20 \mathrm{~min}$ in the freezer, then collected by centrifugation. Finally, the RNA was dissolved in 5 $\mathrm{ml}$ of buffer.

The RNA thus prepared was then divided into two portions, and one was oxidized with $0.0025 M$ sodium periodate (from a freshly prepared stock solution) for $30 \mathrm{~min}$ at room temperature in the dark. Then both the oxidized and control samples were treated with excess ethylene glycol (two drops) for 5 min in the dark to destroy any remaining periodate. The RNA was collected by ethanol precipitation, resuspended in $2 \mathrm{ml}$ of water, and dialyzed overnight against 1 liter of water (changed once).

Attached amino acids were then stripped from the RNA as described below. Then the RNA was precipitated with ethanol, collected, resuspended in $1 \mathrm{ml}$ of water, and dialyzed against 1 liter of water overnight.

The acceptor activity of the RNA was measured as the amount of $\left[{ }^{14} \mathrm{C}\right]$ valine that could be attached to the RNA in the presence of excess enzyme. The reaction mixtures contained, in $0.5 \mathrm{ml}$, approximately 2-8 $A_{26 n}$ units of RNA, $50 \mu \mathrm{mol}$ of Tris ( $\mathrm{pH} 7.3$ ), $5 \mu \mathrm{mol}$ of $\mathrm{MgCl}_{2}, 5 \mu \mathrm{mol}$ of $\mathrm{KCl}, 1 \mu \mathrm{mol}$ of glutathione, $1 \mu$ mole of dipotassium ATP, $0.1 \mu \mathrm{mol}$ of $\left[{ }^{14} \mathrm{C}\right]$ valine ( $25 \mu \mathrm{Ci} / \mu \mathrm{mol}$ ), and excess enzyme in the form of crude extract. All reagents were added at $0^{\circ}$; then the mixtures were incubated for $20 \mathrm{~min}$ at $37^{\circ}$. The reaction was stopped by precipitation with $3 \mathrm{ml}$ of cold $5 \%$ trichloroacetic acid; the precipitates were then collected on glass-fiber filters and the radioactivity was measured.

Preparation of crude cell-free extracts. Bacteria were harvested and concentrated tenfold in $6 \mathrm{mM}$ phosphate buffer ( $\mathrm{pH} 7.3$ ) containing $0.4 \mathrm{ml}$ of 2 -mercaptoethanol per liter. They were disrupted with a Branson Sonifier. Cell debris was removed by centrifugation at $27,000 \mathrm{~g}$ for $10 \mathrm{~min}$.

Purification and fractionation of $t R N A$. Labeled cells were precipitated with trichloroacetic acid, incubated with sodium dodecyl sulfate, and extracted with phenol as described by Wong et al.. (1969). The RNA thus obtained was then collected by precipitation with ethanol, and the $t R N A$ was extracted with $2 \mathrm{~N} \mathrm{LiCl}$ (at room temperature), as described by Avital and Elson (1969). The tRNA was finally precipitated twice with ethanol, $12 \mathrm{mg}$ of carrier tRNA was added, and the tRNA was resuspended 
in the starting buffer for column fractionation. The procedure for the benzoylated DEAE-cellulose (BD-cellulose) columns has been described previously (Marchin et al., 1972).

Assay of valyl-tRNA by $\mathrm{NH}_{2} \mathrm{OH}$ treatment. The amount of valyl-tRNA in crude RNA preparation labeled with radioactive valine was determined by treating the RNA with hydroxylamine and measuring the decrease in acid-insoluble radioactivity. The methods are those of Wong et al. (1969), except that for valyl-tRNA the time of incubation with hydroxylamine was increased to $3.5 \mathrm{hr}$. This length of time was necessary to remove all of the valine.

Other methods. Transfer RNA was deacylated by incubation in $1.8 \mathrm{M}$ Tris $(\mathrm{pH}$ 8 ) at $37^{\circ}$ for $3 \mathrm{hr}$. The unusually long time was necessary to remove valine.

Treatment of crude extracts with Pronase was at an enzyme concentration of 1 $\mathrm{mg} / \mathrm{mI}$; mixtures were incubated for $45 \mathrm{~min}$ at $37^{\circ}$.

\section{RESULTS}

Valyl-tRNA synthetase catalyzes the attachment of valine to its cognate tRNA species; subsequently, the valine is transferred from the tRNA into protein. After $\mathrm{T} 4$ infection the overall rate of valine incorporation into protein is decreased twofold, and this decrease is the result of an actual reduction in the rate of peptide chain growth (Gausing, 1972). This change could, a priori, be a consequence of the phage modification of valyl-tRNA synthetase. We were able to test this possibility by means of $v s 2$, a mutant of $\mathrm{T} 4$ that fails to carry out the modification (McClain et al., 1975); if true, us2 should have a different rate of protein synthesis from wildtype $\mathrm{T} 4$. We therefore measured the rate of amino acid incorporation into cells infected with these phages, choosing a time relatively late after infection in order to make sure that all the enzyme was modified and, therefore, to increase the changes of detecting an effect of modification; previous studies (Chrispeels et al., 1968) had shown that although some enzyme is modified by $5 \mathrm{~min}$ after infection (at $30^{\circ}$ ), the process is not complete until $20 \mathrm{~min}$. Fig- ure 1 shows the incorporation of $\left[{ }^{14} \mathrm{C}\right]$ valine into acid-precipitable material in uninfected and infected cells. The rate of incorporation was identical for cells infected with $v s 2$ and with wild-type $\mathrm{T} 4$ and in both was reduced $50 \%$; modification, therefore, does not affect the overall rate of protein synthesis in phage-infected cells and is not the cause of the observed reduction.

Since the immediate product of the enzyme reaction is valyl-tRNA we measured its amount in the cell as the fraction of the total valine-acceptor tRNA that is in aminoacylated form. RNA was extracted from uninfected and T4-infected cells under conditions designed to preserve the aminoacyl linkage. Then the $3^{\prime}$-ends of tRNA molecules not protected by an attached amino acid were oxidized with periodate. Finally, the protected molecules were assayed by stripping and charging with radioactive valine. As shown in Table 1, the level of charging of valine tRNA was high; similar values have been reported by others for uninfected cells $(85 \%$ by Böck et al. (1966), $75 \%$ by Morris and DeMoss (1965)).

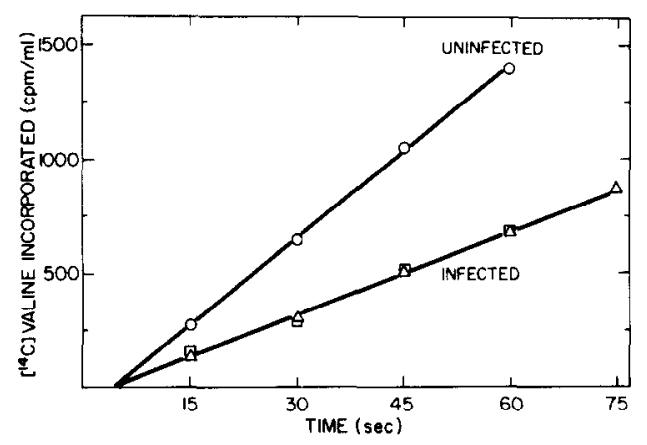

Fig. 1. Rates of valine transfer into protein. Circles, uninfected cells; squares, cell infected with wildtype T4; triangles, us2-infected cells. A culture of NP4 at $1.6 \times 10^{8}$ cells $/ \mathrm{ml}$, grown in minimal medium at $30^{\circ}$, was divided into three portions: One was left uninfected, the second was infected with wild-type $\mathrm{T} 4$, and the third was infected with us 2 ( 5 phage/cell). After $10 \mathrm{~min}$ the cultures were superinfected (again with 5 phage/cell). At $30 \mathrm{~min}$ after infection $\left[{ }^{14} \mathrm{C}\right]$ valine was added to a concentration of $500 \mu M(0.5$ $\mu \mathrm{Ci} / \mu \mathrm{mol}) ; 1-\mathrm{ml}$ samples were removed at 15 -sec intervals thereafter and added to an equal volume of cold $10 \%$ trichloroacetic acid. The uninfected culture was labeled in the same way. The samples were then filtered and the radioactivity retained on the filters was measured. 
TABLE 1

Fraction of tRNA ${ }^{\text {val }}$ Present as ValyL-tRNA ${ }^{a}$

\begin{tabular}{|c|c|c|c|}
\hline \multirow[t]{2}{*}{ Culture } & \multicolumn{2}{|c|}{$\begin{array}{c}\text { Valine acceptor } \\
\text { activity } \\
\text { (cpm/ } / \mathrm{A}_{\mathbf{2 6 0}} \text { unit) } \\
\end{array}$} & \multirow{2}{*}{$\begin{array}{l}\text { Valyl- } \\
\text { tRNA } \\
\text { (\% of } \\
\text { total } \\
\left.\text { tRNA }^{\text {Val }}\right)\end{array}$} \\
\hline & $-\mathrm{NaIO}_{4}$ & $+\mathrm{NaIO}_{4}$ & \\
\hline Uninfect & 618 & 545 & 88 \\
\hline T4-infected & 224 & 179 & 80 \\
\hline
\end{tabular}

${ }^{a}$ A culture of NP4 grown in minimal medium at $37^{\circ}$ to a density of $10^{9}$ cells $/ \mathrm{ml}$ was divided into two $500-\mathrm{ml}$ portions. One was left uninfected; the other was infected with $\mathrm{T} 4$ at a multiplicity of 5 and superinfected $5 \mathrm{~min}$ later. Phage growth was stopped at $20 \mathrm{~min}$ after infection by the addition of trichloroacetic acid; growth of the uninfected culture was stopped in the same way. RNA was then extracted from each preparation and the valine-acceptor activity was determined before and after periodate oxidation. The reduced activity of T4-infected RNA may be due to greater fragility of the infected cells during RNA extraction and the resulting presence of more ribosomal RNA. The proportion of charged valyltRNA was calculated as $\left(+\mathrm{NaIO}_{4} /-\mathrm{NaIO}_{4}\right) \times 100 \%$. Each value is the average of two determinations.

The extent of aminoacylation seen in T4infected cells was essentially the same as in uninfected cells; the difference was within the range of experimental variation. Therefore, modification of the valyl-tRNA synthetase does not produce any major change in the steady-state amount of the reaction product in the cell.

The above experiment, however, measured only the sum of all tRNA's able to accept valine and wuld not necessarily have revealed relative changes among the species. There are three species of valine tRNA in $E$. coli, a major species that responds to the codons GUA and GUG, and two almost-identical minor species that respond to the codons GUU and GUC (Yaniv and Barrell, 1969, 1971). We examined the relative charging of the major and minor species by labeling the tRNA in vivo with radioactive valine and fractionating it on a BD-cellulose column.

The kinetics of labeling under the conditions of this experiment are shown in Fig, 2, A small amount of high-specific-activity radioactive valine was added to cultures of uninfected or T4-infected cells growing in minimal medium. The total radioactivity in the cells (principally in protein) increased for a few minutes, then leveled off; at this time, presumably, the added radioactive valine was exhausted. As expected from the results in Fig. 1, the initial rate of incorporation was less in the T4-infected cells than in the uninfected cells. The amount of radioactivity in valyl-tRNA was very low in comparison with that in protein; note the 100-fold difference in the scales in Fig. 2. This amount remained more or less constant as long as valine was
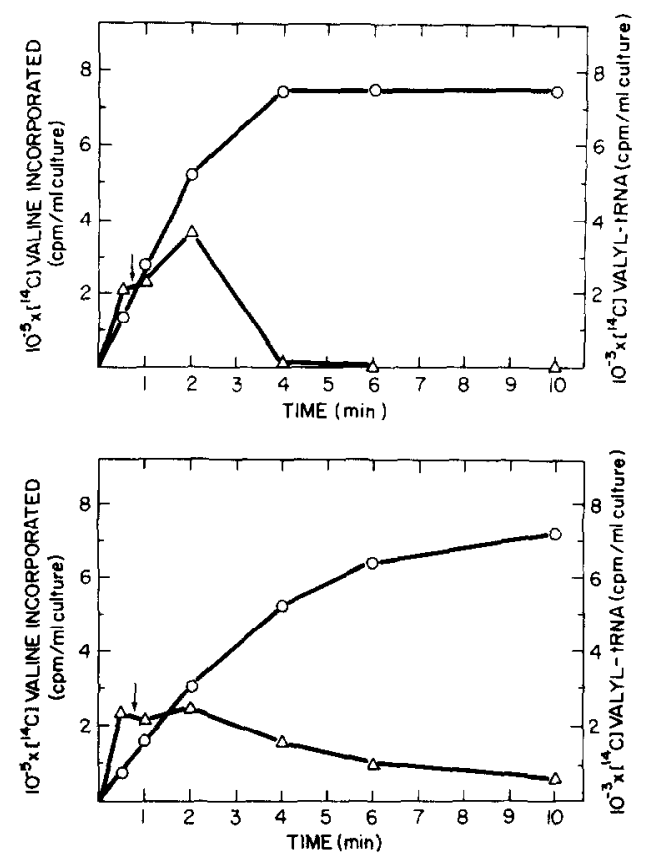

Fig. 2. Incoporation of valine into valyl-tRNA and protein. Top, uninfected cells; bottom, cells infected with wild-type T4, Circles, total valine incorporated; triangles, valyl-tRNA. Cultures of NP4 at $10^{9}$ cells/ $\mathrm{ml}$, grown in minimal mediun at $30^{\circ}$, were labeled with $\left[{ }^{14} \mathrm{C}\right]$ valine at a concentration of $4.2 \mu \mathrm{M}$. At various times, $5-\mathrm{ml}$ portions were removed and added to $10 \mathrm{ml}$ of cold $7.5 \%$ trichloroacetic acid. From each precipitated sample a portion of $1 \mathrm{ml}$ was removed and filtered; the radioactivity retained on the filter indicated the total amount of valine incorporated. From the remainder of the sample, RNA was extracted through the phenol step, and $\left[{ }^{14} \mathrm{C}\right]$ valyl-tRNA was assayed by treatment with $\mathrm{NH}_{2} \mathrm{OH}$. Phage infection was at 5 phage/cell; the cells were superinfected at $15 \mathrm{~min}$, and the labeling was at $30 \mathrm{~min}$. The arrows indicate the time of incubation used in the experiments of Fig. 3 . 
being incorporated; then it dropped, presumably as the radioactive valine was replaced by endogenously synthesized unlabled valine. The level of valyl-tRNA in T4-infected cells, as expected from the results in Table 1, was approximately the same as that in uninfected cells.

For the preparation of labeled tRNA to be analyzed by column fractionation, we chose an incorporation time of $45 \mathrm{sec}$ (arrows in Fig. 2), in order to keep the amount of radioactivity in protein as low as possible. Uninfected cells were labeled with $\left[{ }^{3} \mathrm{H}\right]$ valine, and phage-infected cells with $\left[{ }^{14} \mathrm{C}\right]$ valine. Cell activity was stopped quickly by precipitating the culture with trichloroacetic acid, and tRNA was purified from the combined cultures. In spite of the vast excess of incorporation into protein, almost all of the protein radioactivity was removed in the course of purification, largely in the phenol-extraction step: The valyl-tRNA from uninfected cells, measured as in Fig. 2, was $96 \%$ radiochemically pure, and that from phage-infected cells was $99 \%$ pure.

This labeled valyl-tRNA was next fractionated on a BD-cellulose column (Fig. 3, top). Two peaks of valyl-tRNA are apparent, the smaller one containing the two almost-identical minor species (Yaniv and Barrell, 1971). The patterns of the valyltRNA from T4-infected cells and from uninfected cells were indistinguishable. Phage infection, therefore, and, specifically, phage modification of the host valyltRNA synthetase do not alter the pattern of charging. Furthermore, this pattern is identical to that of the total valine-acceptor tRNA, as determined with tRNA charged to saturation in vitro (Marchin et al., 1972). This similarity implies that the charging levels measured above (Table 1) for unfractionated valine tRNA apply equally to both major and minor species.

This observation, however, does not exclude the possibility that the modification is responsible for maintaining the charging pattern after infection. In that case, the mutant us 2 should have an altered valyltRNA profile. To test this possibility we did a parallel experiment using vs 2 instead of wild-type T4 (Fig. 3, bottom). The us2 pattern, like the wild-type $\mathrm{T} 4$, was indistinguishable from the bacterial pattern; modification, therefore, is not required to maintain the charging pattern.
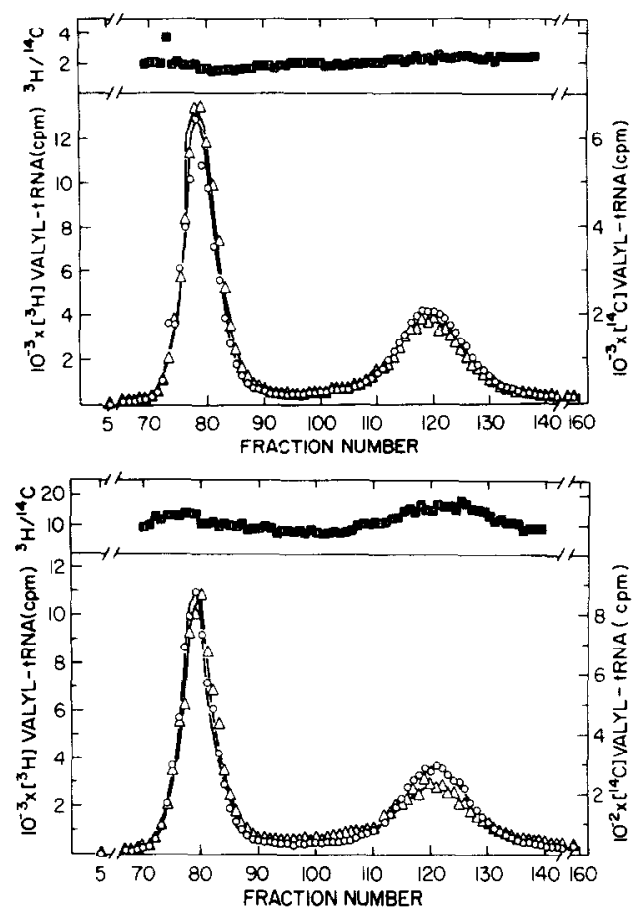

FIG. 3. Fractionation of valyl-tRNA from cells labeled in vivo with radioactive valine. Top, uninfected cells $\left({ }^{3} \mathrm{H}\right.$, circles) and cells infected with wild-type $\mathrm{T} 4$ ( ${ }^{14} \mathrm{C}$, triangles). Bottom, uninfected cells $\left({ }^{3} \mathrm{H}\right.$, circles) and $v s 2$-infected cells $\left({ }^{14} \mathrm{C}\right.$, triangles). A culture of $\mathrm{NP} 4$, grown in minimal medium at $30^{\circ}$ to a density of $1.6 \times 10^{9}$ cells $/ \mathrm{ml}$, was divided into three portions. One was infected with wild-type $\mathrm{T} 4$ at 5 phage/cell, and another similarly with $v s 2$; both were superinfected at $10 \mathrm{~min}$ after infection. At $30 \mathrm{~min}$ they were labeled with $\left[{ }^{14} \mathrm{C}\right]$ valine at a concentration of $4.2 \mu M$ $(260 \mu \mathrm{Ci} / \mu \mathrm{mol}) ; 45 \mathrm{sec}$ later incorporation was stopped by addition of an equal volume of $10 \%$ trichloroacetic acid. The third portion of the culture was left uninfected and was labeled with $\left[{ }^{3} \mathrm{H}\right.$ lvaline (1.3 $\mathrm{Ci} / \mathrm{mmol}$ ). (The lower level of radioactivity for us2 was a consequence of the way this particular experiment was done, and has no physiological significance.) Labeled-culture volumes were $50-100 \mathrm{ml}$. After precipitation, portions of the uninfected cells were mixed with the two phage preparations. Then the labeled tRNA was purified from each of the two mixtures and fractionated on a BD-cellulose column. Recovery of radioactivity from the columns was about $65 \%$. 
As a control in these experiments, we assayed the state of modification of the valyl-tRNA synthetase in the phageinfected cultures from which the labeled valyl-tRNA was prepared. Resistance of enzyme activity to urea was used as a measure of modification (Marchin et al., 1972). The enzyme was assayed in crude extracts of cells sampled just before the labeling period; Figure 4 shows the results, with purified modified and unmodified enzymes included for comparison. The high urea stability of the enzyme from the culture infected with wild-type $\mathrm{T} 4$ indicates that it was completely modified; conversely, the enzyme from the vs2-infected culture behaved like completely unmodified host enzyme. This completeness of modification with wild type is routinely observed with B strains of $E$. coli and, in fact, was one of the reasons for the choice of the host bacteria.

Since in these experiments we found no effects of modification on the attachment of valine to tRNA, we considered the possibility that modification affects a hithertounknown reaction in which the enzyme transfers valine into something other than valyl-tRNA and protein. As noted above (Fig. 2), the amount of valine accumulated in protein is much greater than that in valyl-tRNA, even for very short labeling times. Protein synthesis was therefore inhibited with chloroamphenicol so that the putative unknown reaction would not be obscured. Then the cells were labeled with radioactive valine, and crude extracts were prepared from the labeled cells. Finally, portions of the extracts were assayed for the known valine products by mild alkaline deacylation of tRNA and digestion of protein with Pronase. The results are shown in Table 2. As expected because of the chloroamphenicol inhibition, very little valine appeared in complete protein, although more occurred in peptidyl-tRNA. The majority of the valine appeared in valyl-tRNA. A few percent of the radioactivity was in "resistant material," which may reflect the presence of unbroken cells, incomplete digestion, nonspecific filter hinding, and so forth. The phage-infected cells differed from uninfected only in hav. ing less total valine incorporation and in having somewhat more valine in valyltRNA and less in peptidyl-tRNA; all of these differences can plausibly be attributed to the lower rate of protein synthesis in phage-infected cells (Fig. 1).

Since the sensitivity of a novel product to the treatments used cannot be predicted in advance, any of the fractions could include such a product. For this reason, in order to determine if modification affects the formation of a novel valine-containing product, it is necessary to compare the valine distribution of the mutant vs 2 with that of wild-type T4. The two were virtually identical (Table 2). This experiment would not have detected a small product that is not acid precipitable or one whose formation requires concomitant protein synthesis. These reservations aside, however, we conclude that modification does not affect the formation of any unknown valine-containing product.

One of the changes that modification is known to make in the valyl-tRNA synthetase is an increase in its stability (Marchin et al., 1972). We therefore tested whether modification facilitates phage growth at

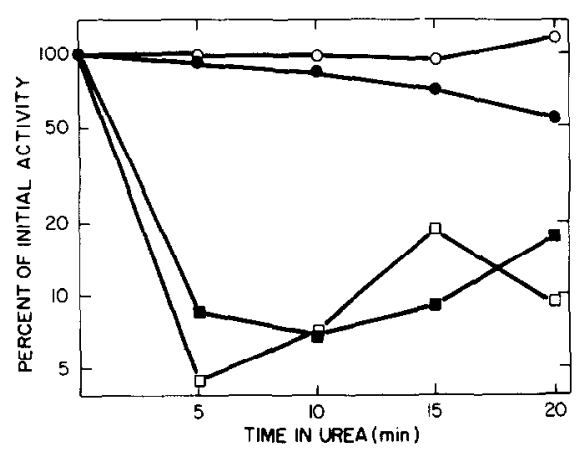

FIG. 4. Enzyme modification in cells from which valyl-tRNA was derived. Open symbols, cells infected with wild-type $\mathrm{T} 4$ (circles) and with us2 (squares). Closed symbols, purified modified (circles) and unmodified (squares) enzymes. In the experiment of Fig. 3 , a portion of each of the phage-infected cultures was removed just before the radioactive valine was added to the remainder, and crude extracts were prepared. Portions of the extracts were incubated with $4 M$ urea for various lengths of time; then the valyl-tRNA synthetase remaining was assayed (Marchin et al., 1972). Purified enzymes were treated in the same way for comparison. 
TABLE 2

Effect of Modification on Various Valine-Containing Products ${ }^{a}$

\begin{tabular}{|c|c|c|c|c|c|c|}
\hline \multirow[t]{2}{*}{ Fraction } & \multicolumn{2}{|c|}{ Uninfected } & \multicolumn{2}{|c|}{ Wild-type T4 } & \multicolumn{2}{|c|}{$v s 2$} \\
\hline & $\mathrm{Cpm}^{b}$ & Percent & $\mathrm{Cpm}^{b}$ & Percent & $\mathrm{Cpm}^{b}$ & Percent \\
\hline A. Total extract & 1541 & $(100)$ & 814 & $(100)$ & 771 & $(100)$ \\
\hline B. Resistant material ${ }^{c}$ & 49 & 3 & 21 & 3 & 34 & 4 \\
\hline C. Protein ${ }^{d}$ & 18 & 1 & 15 & 2 & 15 & 2 \\
\hline D. Valyl-tRNA & 867 & 56 & 504 & 62 & 474 & 62 \\
\hline E. Peptidyl-tRNA ${ }^{\prime}$ & 607 & 39 & 274 & 34 & 248 & 32 \\
\hline
\end{tabular}

${ }^{a}$ A culture of NP4 was grown in minimal medium at $37^{\circ}$ to a density of about $10^{\circ}$ cells $/ \mathrm{ml}$. A portion was then infected with wild-type T4 (5 phage/cell), a second was infected with $v s 2$, and a third was left uninfected. The uninfected culture and, $15 \mathrm{~min}$ after infection, the infected cultures were treated with chloramphenicol at 500 $\mu \mathrm{g} / \mathrm{ml}$. Three minutes later $\left[{ }^{14} \mathrm{C}\right.$ ]valine was added $(0.5 \mu \mathrm{Ci} / \mathrm{ml}, 260 \mu \mathrm{Ci} / \mu \mathrm{mol}) ;$ incorporation was stopped after $25 \mathrm{~min}$, at which time incorporation was still linear, by the addition of an equal mass of crushed ice. Cell-free extracts were then prepared from the labeled cultures. Portions of the extracts were treated as indicated, and the remaining radioactivity precipitable in $5 \%$ trichloroacetic acid was measured.

${ }^{\circ}$ Per $0.1 \mathrm{ml}$ of extract.

${ }^{c}$ Radioactivity remaining after mild alkaline deacylation, followed by two ethanol precipitations and then Pronase digestion. These results were standardized to the rest (without extra precipitations) by comparing parallel samples not treated with Pronase to the values in D.

${ }^{d}$ Radioactivity remaining after deacylation, minus $B$.

${ }^{e}$ Radioactivity remaining after Pronase digestion, minus $\mathrm{B}$.

' Radioactivity sensitive to both deacylation and Pronase digestion: $A-(B+C+D)$.

temperatures that might be inhibitory for the unmodified enzyme. If this were the case, then the mutant vs 2 should grow less well than wild-type T4. Table 3 shows the burst sizes obtained with each strain at various temperatures. The mutant grew as well as wild type throughout; modification, therefore, is not necessary for maximal growth under these conditions.

\section{DISCUSSION}

The phage modification of the bacterial valyl-tRNA synthetase is a seemingly unique and purposeful event. It is apparently limited to the T-even phages (Neidhardt and Earhart, 1966), and no other aminoacyl-tRNA synthetase has been found to be similarly modified (Neidhardt et al., 1969). The process requires the expression of a phage gene (vs), which is probably the structural gene for the modifying protein subunit (McClain et al., 1974). All of the enzyme molecules in the cell are converted to modified form (Chrispeels et al., 1968). Modification improves the stability of the enzyme and the firmness of its binding of tRNA and enables it to charge yeast tRNA (Marchin et al., 1972; Marchin et al., 1974). It is therefore
TABLE 3

Effect of Modification on Phage Growth at High TeMPeratures ${ }^{a}$

\begin{tabular}{ccc}
\hline \multirow{2}{*}{ Temperature } & \multicolumn{2}{c}{ Burst size $^{b}$} \\
\cline { 2 - 3 } & Wild type & vs2 \\
\hline $37^{\circ}$ & 253 & 283 \\
$40^{\circ}$ & 152 & 143 \\
$42^{\circ}$ & 8.5 & 4.7 \\
$44^{\circ}$ & 0.17 & 0.11 \\
\hline
\end{tabular}

${ }^{a} \mathrm{~A}$ culture of $\mathrm{B} / 5$ at a density of about $2 \times 10^{\mathrm{s}}$ cells $/ \mathrm{ml}$, growing exponentially in $\mathrm{C}$ broth, was $\mathrm{di}$ vided into two portions. One was infected with wild-type $\mathrm{T} 4 \mathrm{~B}$ and the other with $v s 2$, each at a multiplicity of about 5 phage/cell, in the presence of $\mathrm{KCN}(0.004 \mathrm{M})$. After an adsorption period of $5 \mathrm{~min}$ at $37^{\circ}$, the cultures were diluted $10^{-4}$ in medium free of $\mathrm{KCN}$ and incubated at the indicated temperature for $1 \mathrm{hr}$. Then lysis was completed with $\mathrm{CHCl}_{3}$ and the number of progeny phage released was measured.

${ }^{\circ}$ Number of progeny phage per original infective center. The number of phage remaining unadsorbed at the time of dilution was $0.01-0.07$ per infective center, and these values have been subtracted from the burst sizes where significant.

surprising that no change has been found in the normal reaction catalyzed by the enzyme. For this reason it is important to determine exactly which possible effects of 
modification have or have not been ruled out by these data.

Many of our conclusions depend on the characterization of $v s 2$ as a nonmodifying mutant. Although it carries an amber mutation (McClain et al., 1975), the position of the vs2 mutation within the vs gene is not known and, hence, neither is the size of the polypeptide fragment made in vs2infected cells. The possibility therefore remains that the fragment is large enough to modify partially the valyl-tRNA synthetase in such a way that it functions normally in vivo, but the modification is so unstable that it cannot be detected by the usual methods. Nevertheless, by all available criteria the enzyme from us2-infected cells is identical to completely unmodified enzyme; furthermore, us 2 in vivo cannot, unlike wild-type T4, stabilize the temperature-sensitive enzyme of a mutant host (McClain et al., 1975).

One effect of modification that might be expected a priori is a quantitative change in some of the reaction parameters. None, however, has been found in vitro (Marchin et al., 1972). Furthermore, we have shown that the rate of valine transfer into protein in vivo is not affected by modification (Fig. 1 ); nor is the level of charging of valyltRNA (Table 1) altered.

Another possible effect is a change in the stability of the enzyme, and indeed the modified enzyme is markedly more stable than the unmodified enzyme (Marchin et al., 1972). This improvement, however, would not seem in itself to confer a selective advantage to the phage, since the temperature sensitivity of phage growth is the same without the modification as with it (Table 3).

Alteration in the substrate specificity of the enzyme is another possible result of modification. We have shown that the modified enzyme cannot attach any of the 20 protein amino acids but valine to tRNA (Marchin et al., 1972). It has not been excluded however, that some other molecule, a nonprotein amino acid or an unrelated compound, could serve as substrate.

The tRNA species specificity apppears to be unchanged both in vitro (Marchin et al., 1972) and in vivo (Fig. 3), at least within the limitations of experimental detectability. If there is a change that was missed, it must involve an unknown, very minor species or possibility a species that cochromatographs with the known valine tRNA species. For instance, a relative change affecting tRNA ${ }_{2 .}^{\text {lal }}$ and tRNA ${ }_{2 \mathrm{~B}}^{\text {ial }}$ might have been overlooked if the sum of the two did not alter much; these two species, however, are nearly identical (Yaniv and Barrell, 1971), and it is not know whether they differ in function.

We have found no evidence that modification affects the formation of any unknown acid-precipitable products (Table 2 ). It has not been eliminated, however, that a small molecule could function as a valine acceptor. For instance, the modified enzyme might catalyze the formation of free valyl-AMP.

Another possibility is that the valyltRNA synthetase has molecular interactions other than simple catalysis and that these functions are affected by modification. In higher organisms, at least, it is known that aminoacyl-tRNA synthetases occur in large complexes (Bandyopadhyay and Deutscher, 1971); interaction with ribosomes is also a priori a possibility.

Even if modification has no effect on enzyme action in the laboratory, the situation could be different in nature. Since there have been no comprehensive studies on the natural ecology of the T-even bacteriophages, we do not know what effects natural environmental conditions or the properties of the natural hosts of $\mathrm{T} 4$ have on the action of the modified enzyme. We have attempted in preliminary experiments to determine whether modification facilitates phage growth under a few conditions that might be encountered in nature. When valine was depleted from the medium after host protein synthesis was shut off, growth of the nonmodifying mutant us 2 appeared to be no more inhibited than that of wild-type T4. When a competing phage, MS2, was present during infection, it was excluded by vs2 as efficiently as by the wild-type phage. In both cases, therefore, modification conferred no advantage. And finally, we examined 47 strains of $E$. coli 
(Wilson, 1973; our unpublished work) that have been recently isolated from nature (hospital patients) and are able to support the growth of T4; all supported the growth of the mutant $v s 2$.

A final possibility is that modification had a function at some time in the past history of $\mathrm{T} 4$ but now is vestigial and has no effect on enzyme action. It seems unlikely, however, that the production of modifying factor sufficiently active to attach to the valyl-tRNA synthetase and to alter some of its properties would have persisted very long in the absence of any selective pressure for its maintenance.

\section{ACKNOWLEDGMENTS}

This work was supported by United States Public Health Service Grants No. GM 08437 and GM 17892, National Science Foundation Grant No. GB 26461, and a United States Public Health Service predoctoral fellowship (No. 1-F1-GM-36,999) awarded to M.M.C. The experiment reported in Table 3 was performed by M.M.C. while she was a postdoctoral student in The Department of Bacteriology at The Univeristy of Wisconsin.

\section{REFERENCES}

Avital, S., and Elson, D. (1969). A convenient procedure for preparing transfer ribonucleic acid from Escherichia coli. Biochim. Biophys. Acta 179, 297-307.

Bandyopadhyay, A. K., and Deutscher, M. P. (1971). Complex of aminoacyl-transfer RNA synthetases. J. Mol. Biol. 60, 113-122.

Böck, A., Faiman, L. E., and Neidhardt, F. C. (1966). Biochemical and genetic characterization of a mutant of Escherichia coli with a temperature-sensitive valyl ribonucleic acid synthetase. J. Bacteriol. 92, 1076-1082.

Chrispeels, M. J., Boyd, R. F., Williams, L. S., and
NeidHARDT, F. C. (1968). Modification of valyl tRNA synthetase by bacteriophage in Escherichia coli. J. Mol. Biol. 31, 463-475.

Gausing, K. (1972). Efficiency of protein and messenger RNA synthesis in bacteriophage T4-infected cells of Escherichia coli. J. Mol. Biol. 71, 529-545.

Marchin, G. L., Comer, M. M., and Neidhardt, F. C. (1972). Viral modification of the valyl transfer ribonucleic acid synthetase of Escherichia coli. J. Biol. Chem 247, 5132-5145.

Marchin, G. L., MülleER, U. R., and Al-Khateeb, G. H. (1974). The effect of transfer ribonucleic acid on virally modified valyl transfer ribonucleic acid synthetase of Escherichia coli. J, Biol. Chem. 249, 4705-4711.

McCt.ain, W. H., Marchin, G. L., Neidhard, F. C., Chace, K. V., Rementer, M. L., and Hall, D. H. (1975). A gene of bacteriophage T4 controlling the modification of host valyl-tRNA synthetase. Virology, 67, 385-394.

Morris, D. W., and DeMoss, J. A. (1965). Role of aminoacyl-transfer ribonucleic acid in the regulation of ribonucleic acid synthesis in Escherichia coli. J. Bacteriol. 90, 1624-1631.

Neidhardt, F. C., and Earhart, C. F. (1966). Phageinduced appearance of a valyl sRNA synthetase acticity in Escherichia coli. Cold Spring Harbor Symp. Quant. Biol. 31, 557-563.

Neidhardt, F. C., Marchin, G. L., McClain, W. H., Boyd, R. F., and Earhart, C. F. (1969). Phageinduced modification of a valyl-tRNA synthetase. J. Cell. Physiol. 74, Suppl. 1, 87-102.

WILSON, J. H, (1973). Function of the bacteriophage 'T4 transfer RNA's. J. Mol. Biol. 74, 753-757.

Wong, J. T., Mustard, M., and Herbert, E. (1969). Regulation of amino acid-specific transfer RNA's in Escherichia coli. Biochim. Biophys. Acta 174, 513-524.

Yaniv, M., and Barrell, B. G. (1969). Nucleotide sequence of $E$. coli B tRNA 222, 278-279.

YANIV, M., and Barrell, B. G. (1971). Sequence relationship of three valine acceptor tRNAs from Escherichia coli. Nature New Biol. 233, 113-114. 